\title{
Wildfire, Water, and Society: Toward Integrative Research in the "Anthropocene"
}

Alicia M. Kinoshita ${ }^{1 *}$, Anne Chin ${ }^{2}$, Gregory L. Simon ${ }^{2}$, Christy Briles ${ }^{2}$, Terri S. Hogue ${ }^{3}$, Alison P. O’Dowd ${ }^{4}$, Andrea K. Gerlak ${ }^{5}$, Alejandra Uribe Albornoz ${ }^{2}$

${ }^{1}$ Civil, Construction, and Environmental Engineering, San Diego State University

${ }^{2}$ Geography and Environmental Sciences, University of Colorado Denver

${ }^{3}$ Civil and Environmental Engineering, Colorado School of Mines

${ }^{4}$ Environmental Science and Management, Humboldt State University

${ }^{5}$ Udall Center for Studies in Public Policy, University of Arizona

*Corresponding author:

Alicia M. Kinoshita

Civil, Construction, and Environmental Engineering, San Diego State University

San Diego State University

5500 Campanile Drive

San Diego, CA 92182-1324

akinoshita@mail.sdsu.edu 


\title{
Wildfire, Water, and Society: Toward Integrative Research in the "Anthropocene"
}

\begin{abstract}
Across the globe, wildfires are increasing in frequency and magnitude under a warming climate, impacting natural resources, infrastructure, and millions of people every year. At the same time, human encroachment into fire-prone areas has increased the potential for ignition, as well as risks and damages to human communities. In an era of intensifying human activities on Earth -the "Anthropocene" -- societal interactions with post-fire landscapes are becoming commonplace. Yet, theories regarding post-fire impacts derived from individual disciplines no longer apply in cases where human interactions are intense. A holistic approach that accounts for interactions between natural and human systems is necessary to understand the altered dynamics of post-fire landscapes. Focusing on the intersection of fire, water, and society, this paper explores an integrative research framework to couple post-fire fluvial and human processes. We review trends in wildfires and growing impacts on humans, how fluvial processes and systems are altered by wildfires, and the potential hazards for human settlements. This review forms a basis for integrating societal concerns, such as vulnerability, economic impacts, and management responses. We then link disciplinary questions into broad interdisciplinary research through an integrative framework. The 2012 Waldo Canyon Fire (Colorado, USA) provides an illustrative case with intense human interactions, both during and after the fire, to formulate critical questions within the integrative framework. Utilizing emergent integrative conceptual frameworks and tools will assist scholars in meeting the challenges and opportunities for broad collaboration, which are necessary to understand and confront wildfires characteristic of the "Anthropocene."
\end{abstract}

Keywords: post-wildfire; fluvial; water; society; interdisciplinary; integrative framework 


\section{Introduction}

Humans are changing Earth's surface at unprecedented rates; at the same time, humans must respond to this rapid change. Maintaining healthy ecosystem services requires that we understand both human impacts and responses and anticipate how interacting landscapes evolve into the future. One process undergoing rapid change is human interactions with wildfires. Across the globe, wildfires are increasing in frequency and magnitude under a warming climate, impacting natural resources, infrastructure, and millions of people every year (Bowman et al., 2009). Simultaneously, human encroachment into fire-prone areas has increased the potential for ignition, as well as risks and damages to human communities, and therefore costs to society (Gorte, 2013). In summer 2012, several wildfires raged across the Colorado Front Range (USA), including the High Park Fire near Fort Collins and the Waldo Canyon Fire near Colorado Springs that displaced hundreds of residents. The Waldo Canyon Fire caused \$353 million in damages and two fatalities. At the time, it was ranked as the most costly fire in Colorado history, only to be matched the following summer by the Black Forest Fire (El Paso County, 2013). These events raise urgent questions about how landscapes respond to disturbance. They also force us to rethink how society responds to altered landscapes. This increasing societal interaction with wildfires is becoming a common phenomenon during the "Anthropocene" - an era dominated by human activity.

Understanding landscapes that are increasingly burned and subjected to intense human interactions requires a holistic and integrated approach. Traditionally, research on the biophysical effects of wildfire has emphasized acute impacts, including runoff and hillslope erosion, stream sedimentation, altered water quality, and degraded biological habitat (Gresswell, 1999; Shakesby and Doerr, 2006; Smith et al., 2011; Moody et al., 2013). Separately, literature 
on human dimensions of wildfires has addressed issues of vulnerability (e.g., Simon, 2012) while also focusing on human responses to the risks and outcomes of fires (e.g., Haight et al., 2004; Cohen, 2010). To fully understand and predict how fire-prone landscapes will evolve with human interactions, we need to develop conceptual and modeling frameworks that emphasize interacting impacts and feedbacks (Bolte et al., 2007; Chin et al., 2014a), while also recognizing that full "recovery" of ecosystems is likely not possible (Vieira et al., 2004). Rather, iterative sequences of alternative stable states (i.e., new "normals"; Collins et al., 2012) may characterize the evolution of landscapes subjected to multiple human-caused drivers of change.

Using the 2012 Waldo Canyon Fire in Colorado (USA) as an illustrative case, we outline potential research directions necessary for understanding the coupling between Earth's surface processes and human activities. The research directions call for a range of interdisciplinary expertise from the natural and social sciences and engineering to understand the complex changes induced by fire. Systems approaches to tackling wildfires are beginning to emerge (e.g., Johnson et al., 2013) and include ways for humans to coexist with wildfires (Moritz et al., 2014). A need exists to catalyze such research by explicitly highlighting fruitful directions for interdisciplinary collaboration. We recognize that human interactions with wildfires are often greatest during and immediately after fires. Thus, we focus on changes resulting from post-fire effects, such as post-fire floods and debris flows at the intersection of fire, water, and society.

First, we discuss wildfires in the "Anthropocene" that point toward a continuing surge in severe wildfires across the American west, concomitant with increasing damages and impacts on human populations. Second, we briefly review key fluvial processes that pose hazardous impacts to humans following wildfire. This review encompasses water quality and hydrology, fluvial geomorphology, and stream ecology, serving as a basis for integrating knowledge from the social 
sciences. Third, we discuss societal impacts and responses to the hazards produced by fluvial processes, focusing on vulnerability, economic implications, and management. Finally, using the case of the Waldo Canyon Fire, we explore overlapping topical areas that may facilitate interdisciplinary understanding and potential areas for integration. This integration allows us to pose new research questions within a systems-level framework. We discuss outstanding research needs, theoretical and methodological challenges, and implications for managing fire-prone landscapes and ecosystems in the "Anthropocene."

\section{Wildfires in the "Anthropocene"}

Wildfires are common and natural occurrences across the world (Paton et al., 2015). Wildfires are necessary to maintain healthy ecosystems to recycle nutrients, improve soil condition, and initiate plant succession (Keane et al., 2008). In mediterranean climates, for example, natural fire frequencies range from 10-15 years in Australia and 10-20 years in South Africa, to 15-40 years in California, USA (Davis and Richardson, 2012; Kruger et al., 2012). In the Front Range of Colorado (eastern slopes of the Rocky Mountains), wildfires burn with average return intervals of less than 30 years in low elevation ponderosa pine forests (Sibold et al., 2006). In some subalpine forests, however, fires have not been noted in over 400 years in this region.

Climatology and anthropogenic climate change influence the patterns of wildfire. Records of fire activity, spanning millennia, suggest that levels of burned biomass before the 1850's corresponded to changes in climate and fuel loads (Marlon et al., 2012). Coupled with the variability in El Niño Southern Oscillation (ENSO), warming climate trends of the 20th and 21st centuries have in particular, increased the susceptibility of mid- to high-elevation forests. Novel mixtures of plants that establish under altered climate can contribute to exacerbated fire 
conditions (Seastedt et al., 2008). For example, high severity crown fires result from the accumulation of fuel and the availability of fuel ladders that carry fire to the top of the forest canopy. Under future climate projections, Spracklen et al. (2009) noted that larger fires are expected, with an increase of up to a 175\% in the Rocky Mountains of Colorado (USA) from 2000 to 2050.

Human activities have also altered wildfire regimes through fire suppression and artificial ignition of fires around the world. Although discerning the degree of human versus climate influence in the historical records is challenging, an uncharacteristic increase in the occurrence of fires in Colorado (USA) is apparent as soon as Euro-American settlers arrived. Settlers provided ample opportunities for ignition through prospecting, salvage logging, and clearing land for ranching (Veblen et al., 2000). Fire suppression efforts after the 1920s, along with the displacement of Native American populations, coincided with decreased ENSO variability that favored conditions for fire, temporarily reducing fire activity (Veblen et al., 2000). Significant buildup of fuel and this "fire deficit" exacerbate potential for catastrophic wildfires (Marlon et al., 2012).

Population growth and human encroachment into fire-prone areas also contribute to the growing hazards from wildfires on society. Direct human interactions with wildfires have consequently increased. Moritz et al. (2014) noted that human population density is becoming a more significant predictor of fire activity than vegetation density. Fires starting and spreading have increased significantly as humans have replaced lightning as the main ignition source of fires, especially where the urban corridor encroaches upon undeveloped areas. In the United States, the National Interagency Fire Center (https://www.nifc.gov) reports that human-caused fires burn more than $9700 \mathrm{~km}^{2}$ (2.4 million acres) per year. Over the last few decades, the 
number of houses in rural areas has decreased (along with an increase in suburban, peri-urban, or urban houses) in the western United States (U.S.) (Figure 1). Rural areas have reduced by as much as 38\% in the 1990s (Figure 1), with continued urban expansion into fire-prone areas. Perhaps most alarming is the capacity for further development, increased fire risk, and potential perturbations to the wildland-urban systems.

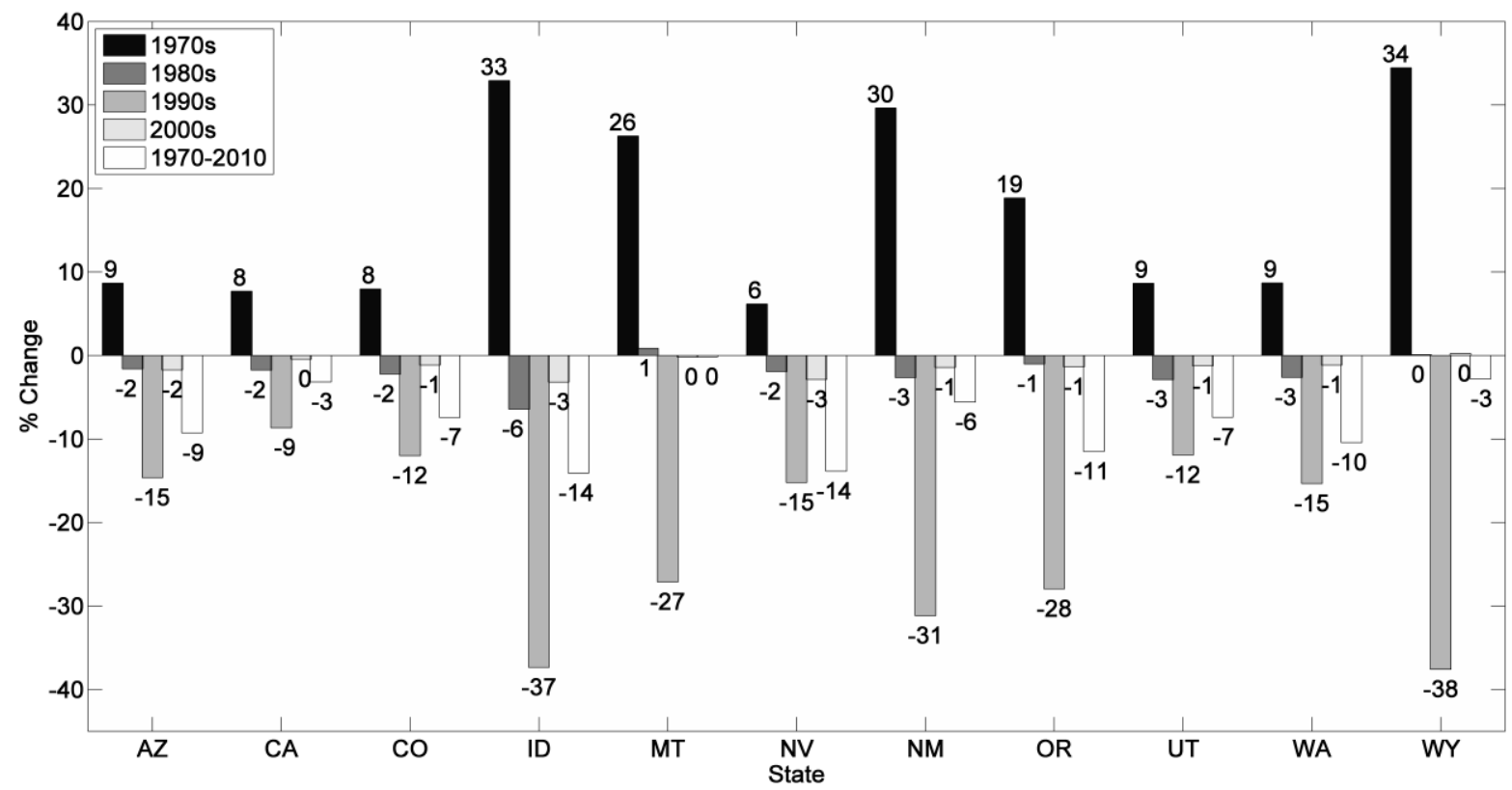

Figure 1: Percentage change in rural areas in western U.S. between 1970 and 2010 for each decade, where $\mathrm{AZ}=$ Arizona, $\mathrm{CA}=$ California, $\mathrm{CO}=\mathrm{Colorado}, \mathrm{ID}=\mathrm{Idaho}, \mathrm{MT}=$ Montana, $\mathrm{NV}=$ Nevada, $\mathrm{NM}=\mathrm{New}$ Mexico, $\mathrm{OR}=$ Oregon, $\mathrm{UT}=\mathrm{Utah}, \mathrm{WA}=$ Washington, $\mathrm{WY}=\mathrm{Wyoming}$ (data source: U.S. Census, 2015 (https://www.census.gov/geo/maps-data/)).

\section{Water and society: post-fire interactions}

\subsection{Fluvial processes after wildfire}

Wildfires induce changes in Earth's surface processes that pose hazards to human settlements with post-fire flash floods a primary hazard for communities downstream (Chong et 
al., 2004). In addition to damage to life and property, risks of flooding pose significant challenges for short- and long-term management. When wildfire occurs, the acute loss of vegetation reduces infiltration and enhances soil water repellency, decreasing soil cohesion and organic matter (DeBano, 2000; Robichaud, 2000). These alterations ultimately increase runoff and flooding potential (e.g., Rulli and Rosso, 2007; Ebel et al., 2012). Kinoshita and Hogue $(2011 ; 2015)$ documented elevated streamflow for seven years after fire in southern California (USA), while dry season flow increased for over a decade. Similar increases in flow are observed in Australia (Lane et al., 2012). The magnitude of these changes depends on the characteristics of the fire, watershed properties, patterns of post-fire precipitation, and recovery of the vegetation (Verkaik et al., 2013; Moody et al., 2013).

In addition to altering rainfall-runoff relationships, wildfires also create sediment hazards for people. Burned hillslopes devoid of vegetation increases the availability of sediment for delivery into river channels. Extreme heat from wildfire also decreases the stability of soils and increases erodibility of the topsoil (Moody et al., 2013). These processes make rill erosion (Sheridan et al., 2007), mobilization of dry ravel (Florsheim et al., 1991), and debris flows (Cannon et al., 2001; Nyman et al., 2015) common after wildfire. Suspended sediment concentrations in stream and rivers typically increase by several orders of magnitude (Troendle and Bevenger, 1996; Silins et al., 2009). Bedload after fire can also increase 20-fold (Beaty, 1994). Thus, post-fire river systems typically become transport-limited (Moody and Martin, 2001). Although sediment concentrations may return toward pre-fire levels within several years (Beaty, 1994), fire-related sediment remaining several hundred years in the fluvial system create legacy effects (Moody and Martin, 2001). Elevated quantities of sediment, coupled with flashier 
hydrological regimes, often induce geomorphic responses that include aggradation, incision, bank widening, channel narrowing, and braiding (e.g., Benda et al., 2003).

Water quality in river systems typically deceases after wildfires. The reduction in water quality occurs as burning releases contaminants—such as lead, mercury, and other trace metals - into the air, which are deposited in soils and vegetation (Odigie and Flegal, 2011; 2014; Burke et al., 2013; Kristensen et al., 2014; Odigie et al., 2016). Thus, wildfires also play an important role in biogeochemical cycling. Increased runoff and erosion after fire remobilizes and transports these contaminants, especially in steep topography (Townsend and Douglas, 2004; Burke et al., 2013; Kristensen et al., 2014). The contaminants from burned landscapes, as well as large quantities of sediment, contribute to elevated pollutant loads downstream (Ranalli, 2004). Nitrates increase up to 40 times (Mast and Clow, 2008; Riggan et al., 1994), for example, along with other metals including lead, cadmium, and mercury (Stein et al., 2012; Burke et al., 2013). These pollutants have significant implications for water management, including the quality of drinking water (Riggan et al., 1994; Stein et al., 2012; Burke et al., 2013) and health concerns (Odigie and Flegal, 2011; 2014; Odigie et al., 2016).

Post-fire changes in runoff, sediment regimes, and water quality also affect the overall health of biotic ecosystems downstream. The resilience of ecosystems and biological communities largely determines the capacity of organisms to adapt and recover (Vieira et al., 2004; Romme et al., 2011). Fire can cause mortality in aquatic fauna (e.g., Rieman et al., 1997), although most studies have found negligible or indiscernible direct impacts to organisms such as fish (Rinne, 1996; Jones et al., 1993), amphibians (Dunham et al., 2007), benthic macroinvertebrates (Minshall et al., 1997; Bêche et al., 2005), and periphyton (Earl and Blinn, 2003; Malison and Baxter, 2010). Causes of direct mortality from wildfire include increases in 
stream temperature (Minshall et al., 1997; Dunham et al., 2007) and toxicity from ash (Spencer and Hauer, 1991; Rinne, 1996) or fire retardant (Jones et al., 1989). In contrast, the loss of riparian vegetation and large floods following fire mobilizes sediment and degrades aquatic habitat, posing indirect effects on organisms (e.g., Bozek and Young, 1994; Pettit and Naiman, 2007). Aquatic organisms that show short-term declines often recover within 1-4 years post-fire (Rieman et al., 1997; Bêche et al., 2005). Recovery of stream ecosystems occurs as vegetation re-establishes and sediment sources decline (Robichaud et al., 2009). Human-induced alterations to landscapes (Neville et al., 2009), however, can amplify the detrimental effects of wildfire and diminish the resilience of ecosystems (Isaak et al., 2010).

\subsection{Societal and human interactions with post-fire fluvial processes}

The changes on Earth's surface induced by wildfire-e.g., flash floods, sedimentation and debris flows, decreased water quality, and degraded aquatic habitats - cause considerable social impacts and responses. Flash floods and debris flows are a common immediate threat to downstream communities, often affecting areas beyond the burned area for more than two years post-fire (Wagner et al., 2013). Storms following the 2003 Old Fire and Grand Prix Fire in California (USA), for example, triggered over 60 debris flows and caused 16 deaths (Santi et al., 2011). In southeast Australia, flash flooding and debris flows following the 2003, 2006, and 2009 fires in Victoria swept away cars, killed a fire fighter, destroyed homes, and buried roads (Nyman et al., 2011). Overall, post-fire flooding and debris flows impact lives, local businesses, private property, and transportation corridors (see also Section 4 for an example from the 2012 Waldo Canyon Fire of Colorado). 
Large-scale erosion within watersheds also increases sedimentation in reservoirs and damage critical infrastructure for water resources (Meixner and Wohlgemuth, 2004; Nyman et al., 2011). The storms following the 2002 Hayman Fire and the 2012 High Park Fire in Colorado (USA), for example, filled reservoirs with sediment and caused intake valves to shut down (Warziniack and Thompson, 2013). Sedimentation in waterways reduces the quality of drinking water and challenges the ability of water providers to deliver safe and clean drinking water to communities (Smith et al., 2011; Emelko and Sham, 2014). Degraded water resources also cause longer-term health impacts related to water-borne illnesses and disease (Tapsell et al., 2002).

Considerable costs arise in mitigating and managing post-fire hazards and risks. Diverse stakeholders, including homeowners and local agencies, bear these costs (Merz et al., 2010). As a result, city bonds, local fees, state and local taxes, and rising insurance premiums (Jensen, 2006) contribute financial pressures within already overburdened municipal agencies (Blonski et al., 2002; Loomis et al. 2004). Removing fire-related sediment from reservoirs, for example, is a major expense. After the 1997 Buffalo Creek and 2002 Hayman Fires in Colorado, Denver Water spent more than $\$ 26$ million for cleaning sediment-laden reservoirs and treating water. The 2012 High Park Fire in Colorado also led to increasing rates to fund capital improvements necessary to maintain a viable source for drinking water (Warziniack and Thompson, 2013). Other costly approaches to reduce the likely effects of catastrophic flooding include improvements to water infrastructure (e.g., piping, pumps, improved water filtration), streambank stabilization (e.g., hydro- mulching, sediment traps, riparian treatments, log deflectors, and seeding to accelerate regrowth of vegetation), and controlling debris with river channels (Robichaud et al., 2000; Emelko and Sham, 2014). In parts of Europe and the U.S., the Burned Area Emergency Response (BAER) program identifies and mitigates imminent threats to 
human life and safety, as well as property and critical natural and cultural resources (Young and Rust, 2012).

Communities at the wildland-urban interface are most vulnerable to the post-fire hazards from flooding, degraded water quality, and public health (Cannon and DeGraff, 2009). Urban expansion into fire-prone areas heightens human exposure to these risks, and in turn increases overall social vulnerability (Montz, 2000; Suriya and Mudgal, 2012). Exposure to a hazard (e.g., homes or communities located within a flood plain), sensitivity to the perturbation (e.g., preexisting challenges of health or mobility), and capacity to adapt and respond to the flood event (e.g., financial resources available to assist the recovery process) influence social vulnerability to flooding at both household and community scales (Adger, 2006; Blakie et al., 2014).

Integrated planning approaches within urbanizing areas can help to reduce future social vulnerabilities (Hamin and Gurran, 2009) and build community resilience to water and sedimentrelated hazards (Berke and Campanella, 2006). These approaches include risk assessments (Plate, 2002), as well as zoning regulations and building codes (e.g., setbacks and requirements of surface permeability) to limit development on high-risk landscapes and help residents withstand the impacts of hazardous events (Berke and Smith, 2009). Preparedness measures, such as improved education and warning systems, are also essential for alerting communities to impending threats and guiding them toward safety (Lopez-Marrero and Tschakert, 2011; De Graff 2014). Such integrated risk management approaches should synthesize best practices from governments, land managers, planners, scientists, and citizens (Aerts et al., 2008, Ashley and Blanksby, 2007). Integrated management should also address key feedback loops linking economic decisions, environmental impacts, planning policy, and social vulnerability (Peterson 
et al., 2014; Chin et al., 2016), utilizing expertize across the social and physical sciences. Thus, in addition to preventing hazardous events from occurring, the goal of management should focus on anticipating the inevitability of periodic flooding where intense human interactions with landscape processes occur (i.e., in the "Anthropcene") and minimizing their impacts (Hamin and Gurran, 2009, Liao, 2012).

\section{Through the lens of the Waldo Canyon Fire}

The Waldo Canyon Fire (Figure 2) began on 23 June 2012 and burned $74 \mathrm{~km}^{2}$ of land, mostly in the Pike National Forest near the city of Colorado Springs, Colorado. The fire was contained on 10 July 2012. About 19\% of the burn was classified as high severity, $40 \%$ moderate severity, and 41\% low severity (Young and Rust, 2012). Most notable about the Waldo Canyon Fire, however, was the potential for high social impacts due to the proximity of the fire to a large city (Colorado Springs with a population of 433,570 people and nearby communities (Figure 3ad)). More than 32,000 residents were evacuated, including 22,000 people within a two-hour period on 26 June 2012 (Martin, 2013). The fire damaged or destroyed 347 homes, mostly in the Mountain Shadow neighborhood, and killed an elderly couple. Insurance claims from loss and damage totaled $\$ 353$ million. Closure of businesses (e.g., Figure 3c) escalated millions of dollars. In addition, the U.S. Forest Service reportedly spent $\$ 13 \mathrm{M}$ fighting the fire. The City of Colorado Springs recorded over $\$ 4 \mathrm{M}$ in overtime wages during and after the fire. Additionally, the Colorado Springs Utilities spent more than $\$ 2.7 \mathrm{M}$ to restore damaged utilities. In light of these diverse and significant costs, the Waldo Canyon Fire was, at the time of occurrence, the most expensive in state history (Wineke, 2012). The costs continued to mount into the years 
following the fire, as efforts focused on mitigating and treating the secondary effects (Figure 3c), including flash floods and sediment debris (Figure 3d).

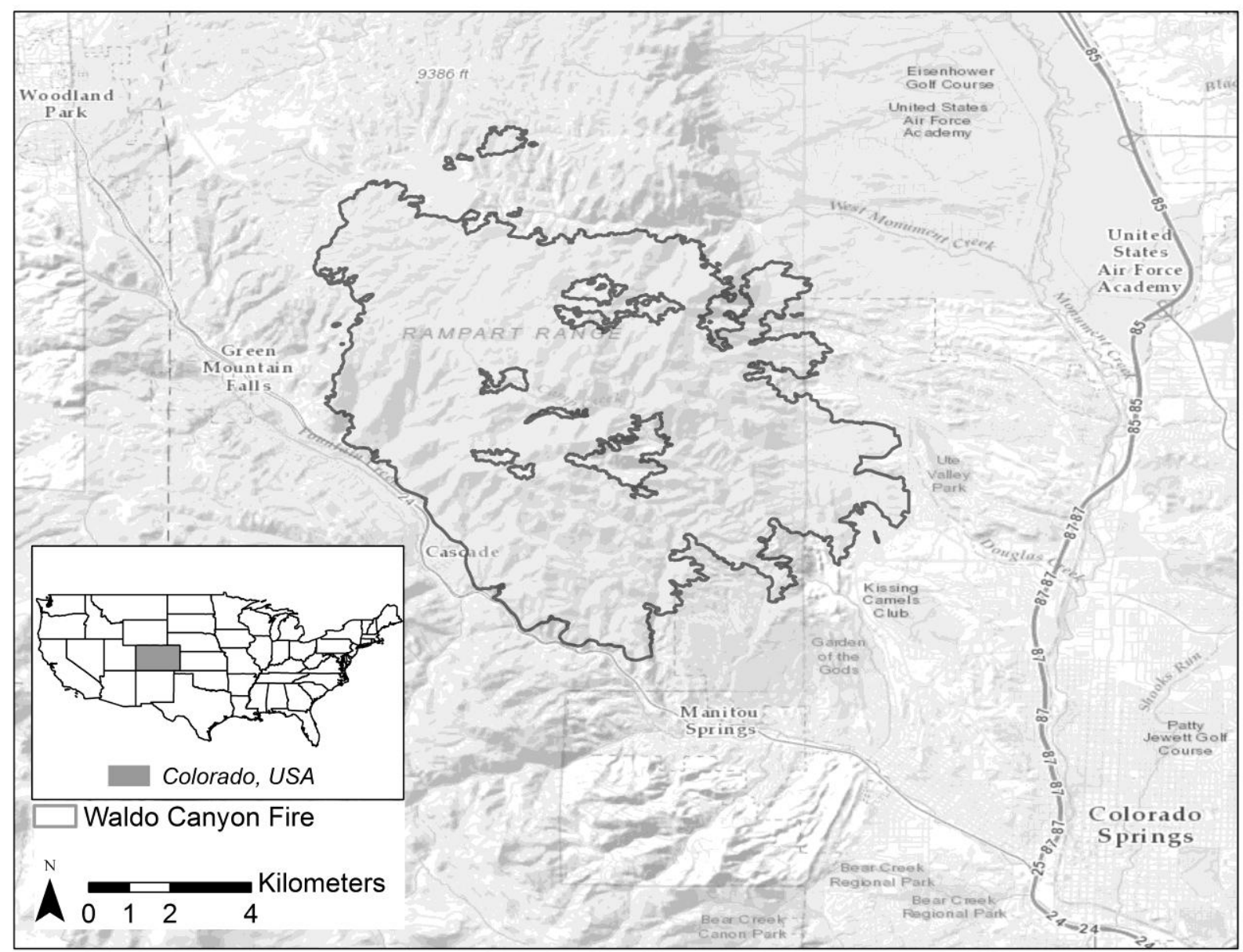

Figure 2: Waldo Canyon Fire in Colorado, USA and surrounding cities (Woodland Park, Manitou Springs, and Colorado Springs), main roads, and streams. 

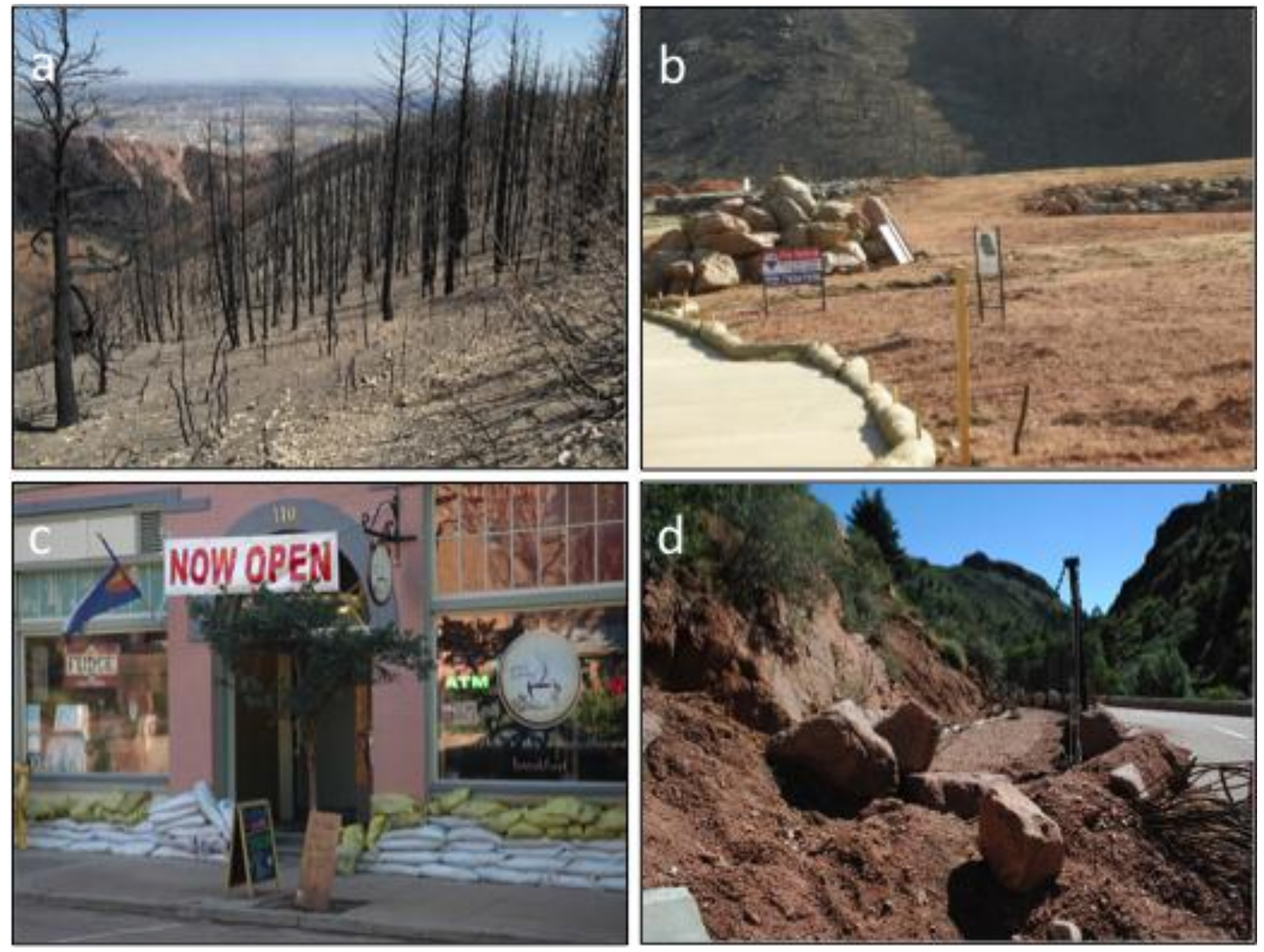

Figure 3: Human impacts of Waldo Canyon Fire: (a) burned forest with Colorado Springs in background (photo taken April 2013); (b) vacant land for sale where homes once stood, against burned forest (photo taken April 2013); (c) coffee house (and other businesses) in Manitou Springs re-open after damage from flash floods induced by fire (photo taken August 2013); (d) debris from Waldo Canyon onto US Highway 24, the main road between Colorado Springs and Woodland Park (photo taken September 2013).

Besides the high economic costs, the Waldo Canyon Fire was an example of complex and intense human interactions with wildfire. The close proximity to a large city created an 
unprecedented collaboration between agencies (at multiple levels) in the post-fire efforts to manage potential risks and hazards to residents (El Paso County, 2013). These agencies focused primarily on mitigating the risks and hazards of flash floods and sediment/debris flows (El Paso County 2013). At the Federal governmental level, the agencies included the U.S. Forest Service (USFS), Federal Emergency Management Agency (FEMA), and Natural Resources Conservation Service (NRCS). Organizations at the city, county, and state levels (the cities of Colorado Springs, Manitou Springs, and El Paso County) also worked alongside local agencies such as the Colorado Springs Utilities, non-profit organizations (e.g., Coalition for the Upper South Platte), and private landowners. These agencies collaborated to implement projects to stabilize hillslopes and slow erosion (i.e. detention basins, reshaped channels). The Colorado Department of Transportation (CDOT) also installed mitigation and advanced warning systems for flash floods. Decision-making, therefore, played an important role in how the burned landscape would recover, and in turn how the recovery process would affect human communities.

In addition, direct human interactions with post-fire processes also characterized the Waldo Canyon Fire. These human actions focused on intervention measures to inhibit the natural processes following fire that would produce erosion, flash floods, and ultimately hazardous to society. Activities included the application of retardants and treatment (e.g., aerial straw and wood chip mulching) (Figure 4a-b) during and immediately after fire to prevent potential erosion. Direct manipulation of hillslope and river channels also continued several years after the fire (Figure 4c-f) to retard movement of sediment down barren hillslopes into stream channels and block sediment transportation toward downstream residential communities. By 2013, 45 sediment detention basins were implemented (Figure $4 \mathrm{c}-\mathrm{d}$ ), as well as $\sim 10 \mathrm{~km}$ of modified river 
channels, 89 manual treatments, and 2,383 debris deflectors, totaling over \$30M in expenses (El Paso County, 2013). Similarly, private landowners also built two tall debris fences at the base of a burned watershed that cost over \$1.5M (Figure 4e-f; Chin et al., 2016).
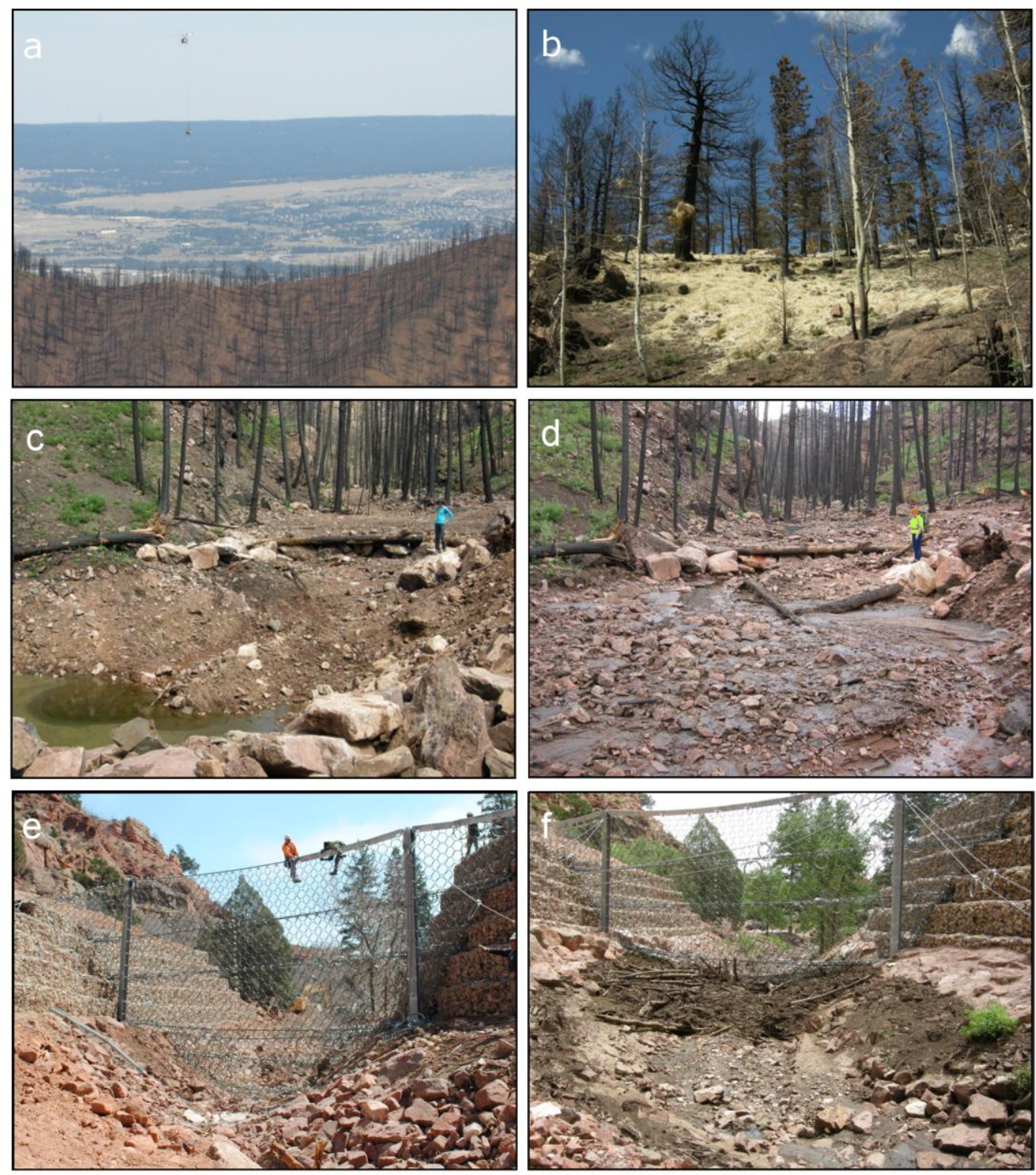

Figure 4: Human responses to Waldo Canyon Fire: (a) aerial mulching after containment of fire

(helicopter is seen in sky, top left of center; photo taken 16 September 2012) (b) straw treatment from aerial application (photo taken 16 September 2012); (c) in-channel modification: sediment basins (photo taken 30 June 2013); (d) sediment basin filled after storms (photo taken 13 July 
2013); (e) sediment fence over $6 \mathrm{~m}$ (20 ft) tall, constructed upstream of residential community (photo taken March 2013 showing construction workers on fence) ; (f) sediment and wood behind fence after storm (photo taken 6 July 2013).

Although mitigating potential hazards associated with post-fire effects (as described in previous sections) are often given high priority to alleviate immediate human concerns, they confound causal connections and make predictions of post-fire processes difficult (Gresswell, 1999; Chin et al., 2016). Artificial manipulation of burned landscapes also affects the cycle of natural recovery within ecosystems, many of which have demonstrated remarkable resiliency (e.g., Yellowstone after the 1988 fire; Romme et al., 2011). Moreover, despite the significant activities implemented after the Waldo Canyon Fire, extremely heavy rainfall and steep granite terrain still produced hazardous flooding that contributed to additional loss of life, property, and critical public infrastructure in the summers of 2012 and 2013 (EL Paso 2013 and CDOT 2014). Thus, a need exists to understand the complex and interactive responses and influences of human activities in the post-fire recovery process, and to incorporate them in predictive models. This understanding requires linking theories from the bio-physical and social sciences.

\section{Toward integrative studies on wildfires in the "Anthropocene"}

\subsection{Core themes}

The core themes common to investigating hydro-geomorphic, ecological and social (environmental governance) systems (Wohl et al., 2014) provide a path for integrating the fluvial and social dimensions of wildfires. These themes include connectivity, feedbacks, tipping points or thresholds, and resiliency. As open systems, the connectivity of landscape components largely 
controls the traits of the system (Bracken and Croke, 2007; Bracken et al., 2013). Bio-physical systems adjust over time to disturbances such as hydrologic events (Poff et al., 1997) and human activity, including land-use changes (e.g., Chin, 2006). These systems exhibit varying degrees of resilience and feedback mechanisms that regulate their behavior (Corenblit et al., 2011; Chin et al., 2014a), including complex, non-linear responses characterized by thresholds (Schumm, 1979). Correspondingly, social or governance systems show connectivity in the flows of information and communication, with decision processes often eliciting feedback loops (Gerlak, 2013; Peterson et al, 2014). The concept of adaptiveness in social systems (Folke et al., 2005; 2010) relates to the idea of resiliency in natural systems. Adjustments to perturbations through feedback mechanisms also characterize social systems, including thresholds that may be crossed. These themes, therefore, are considered promising foci for interdisciplinary research linking across physical and social aspects of human-landscape systems, including the effects of wildfire (Harden et al., 2014).

\subsection{Applying the Interactive, Integrative and Iterative Framework to the Waldo Canyon Fire}

The Interactive, Integrative, and Iterative (III) Framework for Human-Landscape Change provides a useful conceptual tool to link questions centering on connectivity, feedbacks, tipping points/thresholds, and resiliency. The III framework (Chin et al., 2010; 2014b) focuses on the core interactions among physical, biological, and social processes in response to perturbations within landscapes_ — such as human-induced soil erosion, clear-cutting, or installation and removal of dams in rivers. In this case, wildfires (the perturbation) may be sufficiently strong to tip the system across a threshold (left box Figure 5). The resulting adjustments within the interacting systems and processes (center of Figure 5) ultimately change the conditions of 
vulnerability and resilience in bio-physical systems and human communities (right box Figure 5; e.g. elevated streamflows and impacted communities). The environmental and human context in which the perturbation occurs (top arc Figure 5) determines the initial vulnerability and resilience of the human and bio-physical systems to the perturbation. It also contributes the background processes (e.g., perceived risk) that determine the resulting conditions of the biophysical and human systems after adjustment to the perturbation. The changes, in turn, elicit environmental responses and modifications in human actions that potentially feed back to the original causes (bottom arc Figure 5). Feedback responses at various levels (local and regional) occur through policy along with mitigation and adaptation strategies to environmental stress, as well as behavioral changes.

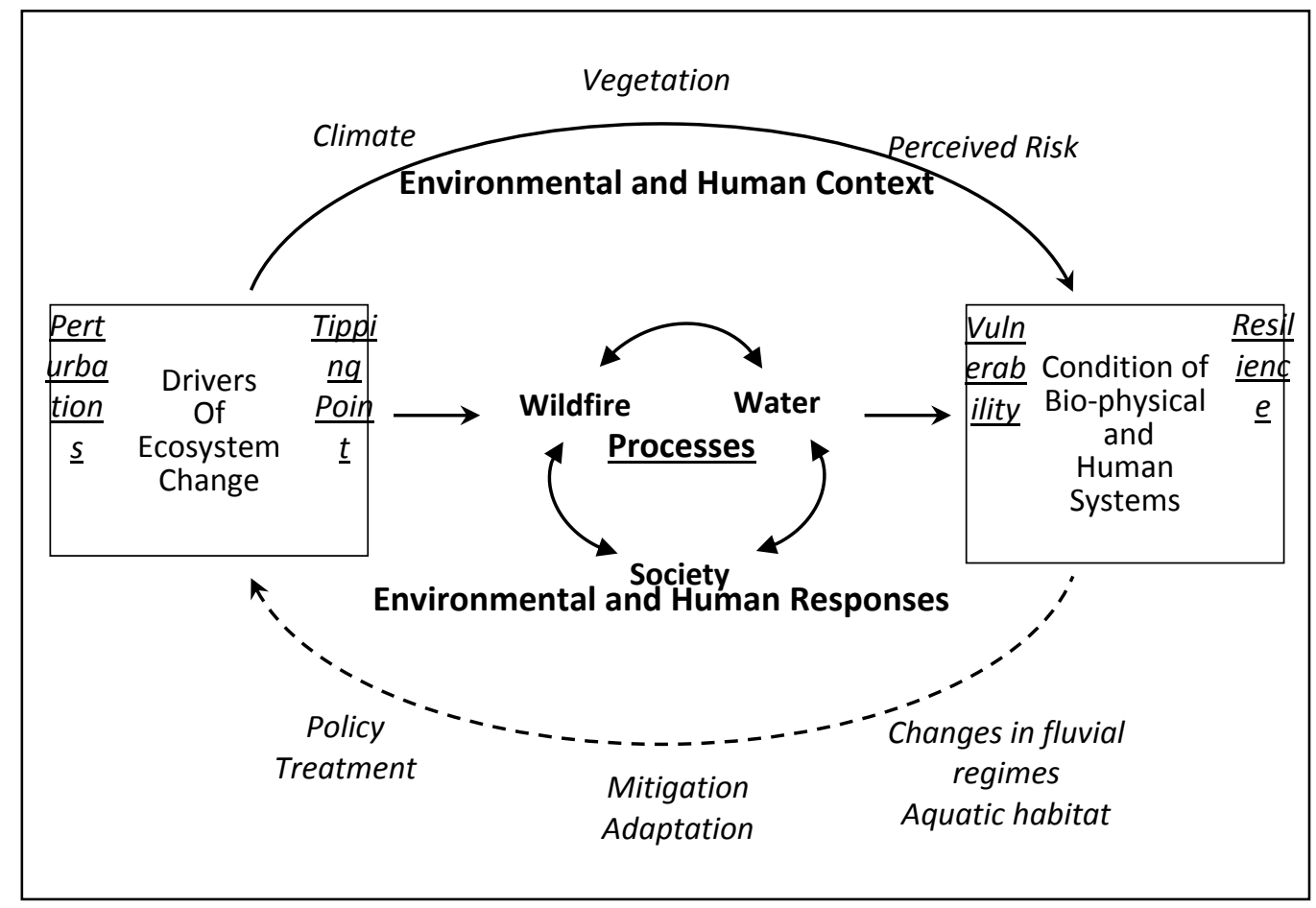

Figure 5: The Interactive, Integrative, and Iterative (III) Framework for Human-Landscape Change as applied to the wildfire, water, and society nexus. It provides an integrative view that 
links impacts with feedbacks. The top arc represents the background environmental and human processes that provide a context for the perturbations and resulting changes. The middle arrow represents adjustments and impacts after a perturbation. The bottom arc represents environmental and human feedback responses.

The III Framework for Human-Landscape Change is particularly useful for conceptualizing problems in the "Anthropocene" and anticipating solutions for the future, even though it is just one of several frameworks that bridge disciplinary divides in tackling complex environmental systems (see, for example, theory on social-ecological systems; Berkes et al., 2003). Distinct from other frameworks, the III model explicitly identifies the physical, as opposed to ecological, landscape processes (Wohl et al., 2014). The framework emphasizes adjustments over time through interacting impacts and feedbacks in response to disturbances in the system-resulting in iterative changes in system states in the evolution of the landscape (Figure 6). When applied iteratively, the III is useful for articulating and understanding changing human-landscapes over time, and thus for anticipating changes that will occur on Earth's surface. (After Chin et al., 2010). It also considers the longer-term, cumulative changes that characterize the evolution of geomorphic systems, including legacy effects from past disturbances (Wohl and Merritt, 2007; James, 2013) that pose varying initial conditions of vulnerability and resilience. For example, Moody and Martin (2001) found that residence times for eroded sediment after a wildfire in the Colorado Front Range exceeded 300 years, much greater than the recurrence interval of fire in the area. The erosional and depositional features, therefore, become legacies from wildfire and serve as new initial conditions for subsequent wildfire and flood sequences during landscape evolution. 


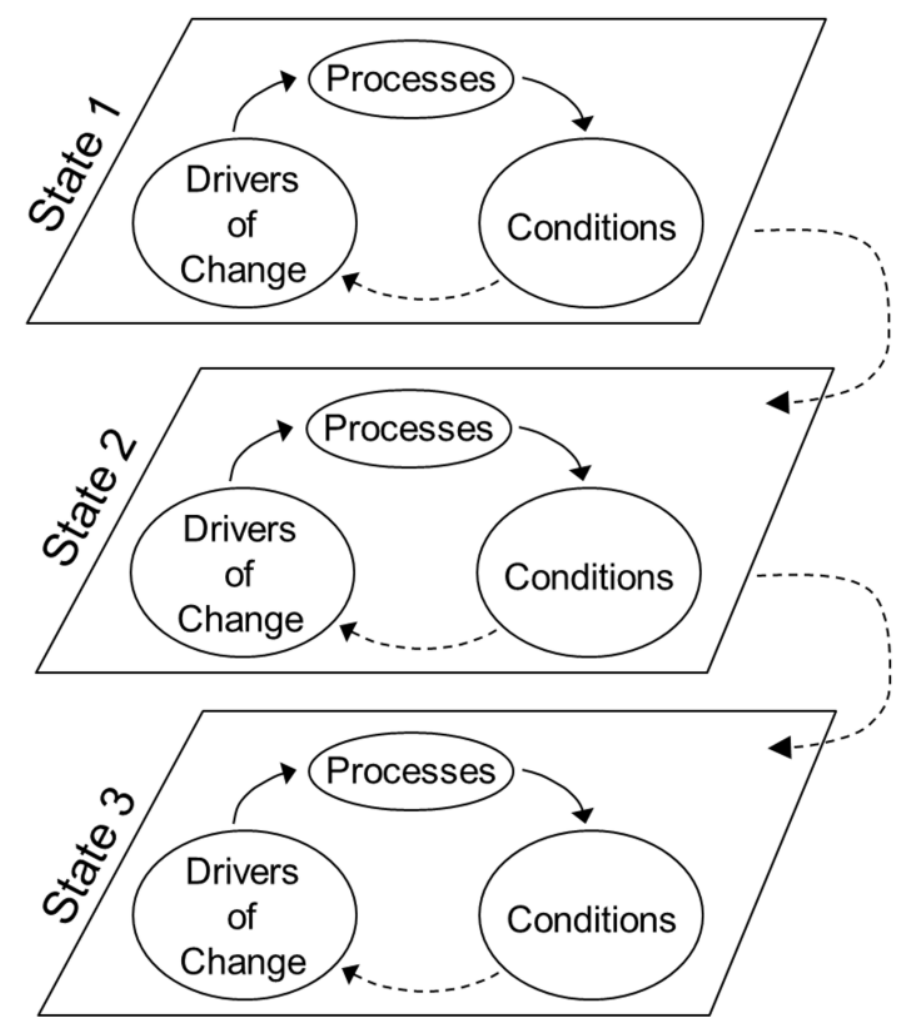

Figure 6. Iterative states in the evolution of human-landscape systems produced by interacting impacts and feedbacks. New states occur when thresholds are crossed and the system does not return to pre-disturbance conditions (After Chin et al., 2010). In this context, State 1 represents post-fire adjustments and responses (i.e., Figure 5). State 2 occurs when the system is no longer able to recover to pre-fire conditions. State 3 is a potential new equilibrium.

The III framework provides a useful conceptualization of the complex human-landscape interactions induced by the Waldo Canyon Fire. Ignition in an urban-fringe location (the perturbation, left box; Figure 5) causes post-fire floods and debris flows and reduced biological habitats and water quality. At the same time, interacting environmental and human processes include application of aerial retardants to inhibit erosion and post-fire management responses, such as straw and wood mulch (Figure 4). These interactions may elicit feedbacks among the 
social and bio-physical processes themselves. Regardless, the perturbation and adjustment processes result in reduced resilience and increased vulnerability in both bio-physical and human systems (right box, Figure 5). Such degraded conditions may prompt further human and environmental responses (bottom arc; Figure 5).

An example of a complex human response to the risks and hazards following the Waldo Canyon Fire was the construction of large debris nets (Figures 4 e-f; bottom arc Figure 5; mitigation and adaptation) to protect property and lives. Instead of facilitating recovery of the burned landscapes, the debris net interrupted sediment transport and prevented coarse particles from propagating downstream. The decreased roughness caused further channel erosion, which prompted the landowners to pave the river channel (Chin et al., 2016). The additional human response of paving the eroded river channel segment changed the form and function of the river system further, acting as a tipping point in the system, whereby a return to a pre-fire state (i.e. recovery) is no longer possible. In this case, the post-fire landscape reaches State 2 (Figure 6).

As scientific knowledge advances regarding the complex human-landscape interactions following wildfires, the environmental impact of post-fire practices and sustainable management strategies may emerge. Over time, these changing interactions may enable the burned system to regain some of its connectivity and lost functions, even though this "recovery" may be partial. Such iterative states could continue until the landscape system reaches a new equilibrium (State 3; Figure 6). Or, in the case of persistent human interruption, the system may remain in a perpetual state of adjustment.

\subsection{Posing Integrative Research Questions}


The case of the Waldo Canyon Fire underscores the need to understand the multiple dimensions of human interactions with wildfire within an integrated framework capable of articulating these interactions. The complex interactions include humans affecting the cycle of wildfires, to wildfires impacting people, to responses such as strategies for mitigating hazards from wildfires. Therefore, to fully understand and anticipate how fire-prone landscapes will evolve under increasing human intervention, -- i.e., in the "Anthropocene," -- new approaches are needed to connect the impacts of fire with the human responses to the fire and understand how these responses, in turn, affect the landscape. The use of conceptual frameworks that emphasize interacting impacts and feedbacks (Figure 5) are critical, while recognizing that multiple thresholds within both adjusting natural and human processes will make predictions of change difficult. Moreover, conceptual frameworks must accommodate incomplete "recovery" of ecosystems when they are subjected to persistent, multiple human-caused drivers of change. Instead, iterative sequences of new stable states (i.e., Figure 6, repeated new definitions of "normal" (Collins et al., 2012)) will likely characterize the evolution of fire-prone landscapes. Such an integrative approach highlights common core themes for investigating wildfire, hydrogeomorphic, and social (governance) systems, as outlined above.

Accordingly, we pose a series of interconnected example research questions within this framework, deriving from the Waldo Canyon case study, at the intersection of post-fire fluvial and social systems. These questions illustrate an integrated, interdisciplinary approach to tackling post-fire research in the new era (Figure 7).

\section{A. Initial state of landscape before disturbance (pre-historical context)}


A1. What is the fire regime in the area and how have climate change and human activity influenced this regime?

A2. How has forest management influenced the hydrological, geomorphological and biotic systems?

A3. How has the built landscape evolved and contributed to human disturbances?

B. Interactions among natural and social processes induced by fire

B1. How do biotic communities interact with sediment dynamics and channel morphology in varying degrees of burn?

B2. How do these biotic and geomorphic interactions vary with runoff response?

B3. How do fire management treatments and policies affect the dynamic hydrogeomorphological-biotic interactions and responses?

\section{Management responses and changing human-landscape systems over time}

$\mathrm{C} 1$. What are the trajectories of landscape change under different forest policy and management regimes?

C2. What are the feedbacks between altered landscape processes and human behaviors?

C3. How do changing landscapes affect the ecosystems services that they provide, and how do feedback responses trigger decisions that influence further change?

Tackling these questions requires interdisciplinary expertise in paleoecology and climate science (A1), hydrology (A2, B2, B3, C1), geomorphology (A2, B1, B2, B3, C1), ecology (A2, B1, B2, B3, C1), human geography/sociology (A3, C1, C2), economics (C2, C3), and 
political/decision science (A2, C2, C3). In this integrated approach, answering questions using knowledge from one discipline will improve the ability to answer other disciplinary questions. For example, knowing the fire cycle and the influence of climate change (A1) will help us understand the time scales of process adjustments (B1, B2) - i.e., the time frame for a possible stable state in the evolution of the landscape (Figure 6) — which will yield insight into the trajectories of landscape change under different policy regimes (C1), as well as changes in ecosystem services (C3). Echoing Beschta et al. (2004), such an interdisciplinary approach will contribute to a timely and holistic understanding of wildfires, while accounting for inevitable and increasing human interactions (Gresswell, 1999; Wohl, 2013).

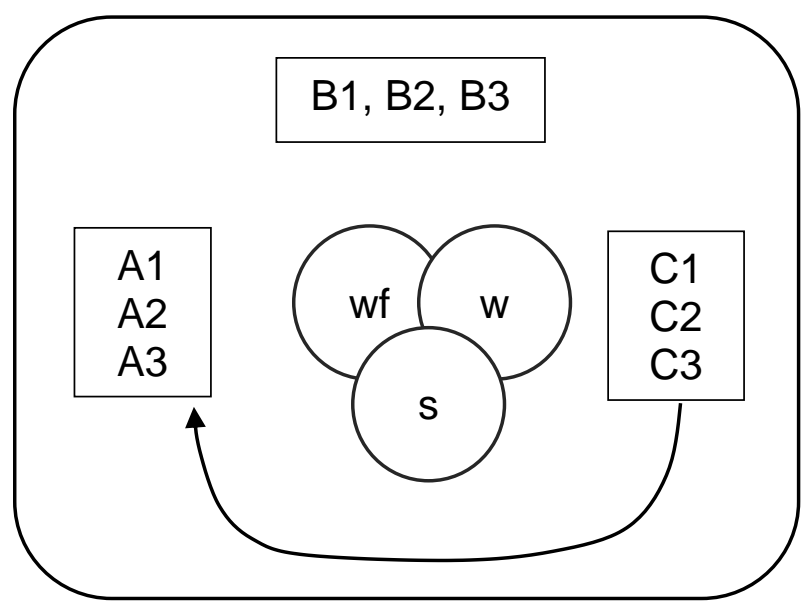

Figure 7. An integrated interdisciplinary approach for post-fire research. The interacting processes are $\mathrm{wf}=\mathrm{wildfire}, \mathrm{w}=\mathrm{water}, \mathrm{s}=$ social. Letters and numbers refer to the research questions in the text, where " $\mathrm{A}$ " is the initial state of landscape before disturbance; " $\mathrm{B}$ " denotes the interactions among bio-physical and social processes induced by wildfire; and "C" refers to the human responses and changing human-landscape systems over time. The bottom arrow is analogous to the bottom arc in Figure 5, where environmental and human responses provide feedbacks to the original state of the landscape. 


\section{Outstanding Needs, Challenges, and Opportunities}

An urgent need exists to understand the interactions and feedbacks among wildfire, water processes, and society. First, we need to develop predictive understanding of the coupled hydrological, geomorphic and ecological responses within burned landscapes, using interdisciplinary knowledge amassed over the past several decades. Such information is vital for understanding the fundamental processes, functions, and feedback relationships altered by fire, and ultimately for maintaining healthy ecosystem services for human communities in the face of change. Second, in an era of intense human interaction with landscapes, we need to fully integrate human activities into these coupled responses. This approach entails better understanding of the historical context of human impacts, policies, and management practices under which landscapes have evolved, as well as ongoing wildfire mitigation. Third, in light of complex feedback loops (Chapin et al., 2006; Chin et al., 2016) in the post-fire human-landscape system, we need to develop effective policies and strategies for mitigating and adapting to risk

(i.e., bottom arc Figure 5). Recognizing that disturbance is itself an agent of recovery, strategies should place priority on enhancing capacity for burned landscapes to recover (Beschta et al., 2004), rather than on changing the trajectory of recovery.

Challenges to meet the needs outlined above remain with respect to data, theory, and methods. Abundant and diverse types of observational data, such as field-based or remotelysensed information exist across various ecosystems, spatial and temporal-scales, and research disciplines. To advance the integrative science of wildfire, humans, and river systems, we must synthesize and analyze historical pre- and post-fire information across multiple disciplines and also develop new data and methods that can complement existing datasets. Tackling broad 
interdisciplinary research questions also requires collaboration among diverse scientists, especially in bridging the social-natural scientific divide, where different languages, data, and tools to address the same problem exist (Bracken and Oughton, 2006). Particular difficulties arise when quantitative models are capable of representing only portions of human-landscape interactions, necessitating the use of mixed methods (Lach, 2014). Modelers therefore need to collaborate with scientists who work on the ground to fill in gaps in models; domain scientists must learn computational thinking and sufficiently understand mathematical models to improve model parameterization.

An emergent set of integrative analytic and modeling tools, such as simulation approaches, provide the ability to integrate data from multiple temporal and spatial scales and various fields of research. These tools enable the incorporation of feedbacks from human behavior and decision-making (Barton et al., 2010; Zvoleff and An, 2014; Chin et al., 2015). The U.S. National Research Council (2011) noted the critical importance of successfully incorporating human interaction in modeling the mechanics of Earth surface systems. These modeling tools provide a new avenue for addressing complex interactions within the nexus of wildfires, water, and society — and in general, for answering a grand challenge recently identified: How will Earth's surface evolve in the "Anthropocene?" (NRC, 2010). 


\section{References}

Aerts, Jeroen CJH, et al. "Dealing with uncertainty in flood management through diversification." Ecology and Society 13.1 (2008): 1-17.

Adger N. 2006. Vulnerability. Global Environmental Change 16:3 268-281, P.72

Ashley, R. M. and Blanksby, J.: Towards integrated approaches to increase resilience and robustness for the prevention and mitigation of flood risk in urban areas, Advances in Urban Flood Management, London, Taylor and Francis, 415-432, 2007.

Barton, C.M., Ullah, I.T., Bergin, S.M., 2010. Land-use, water, and mediterranean landscapes: modeling long-term dynamics of complex socioecological systems. Philosophical Transactions B of the Royal Society 368, 5275-5297.

Beaty, K.G., 1994. Sediment transport in a small stream following two successive forest fires. Canadian Journal of fisheries and Aquatic Sciences 51, 2723-2733.

Bêche, L.A., Stephens, S.L., Resh, V.H., 2005. Effects of prescribed fire on a Sierra Nevada (California, USA) stream and its riparian zone. Forest Ecology and Management 218, 37-59.

Benda, L., Miller, D., Bigelow, P., Andras, K., 2003. Effects of post-wildfire erosion on channel environments, Boise River, Idaho. Forest Ecology and Management 178, 105-119.

Berke, P.R. and Campanella, T.J., 2006. Planning for postdisaster resiliency. The Annals of the American Academy of Political and Social Science, 604(1), pp.192-207.

Berke, Philip, and Gavin Smith. "Hazard mitigation, planning, and disaster resiliency: Challenges and strategic choices for the 21st century." Building Safer Communities. Risk Governance, Spatial Planning and Responses to Natural Hazards 1 (2009): 18.

Berkes, F., Colding, J., Folke, C. (Eds.), 2003. Navigating Social-Ecological Systems: Building Resilience for Complexity and Change. Cambridge University Press, New York.

Beschta, R.L., Rhodes, J.J., Kauffman, J.B., Gresswell, R.E., Minshall, G.W., Karr, J.R., Frissell, C.A., 2004. Postfire management on forested public lands of the western United States. Conservation Biology 18, 957-967.

Blaikie, Piers, et al. At risk: natural hazards, people's vulnerability and disasters. Routledge, 2014.

Blanchi, R., Leonard, J.E., Leicester, R.H., 2006. Lessons learnt from post-bushfire surveys at the urban interface in Australia. Forest Ecology and Management, 234(1), S139.

Blonksi, K.S., M.E. Morales, and T.J. Morales. 2002. Proceedings of the California's 2001 Wildfire Conference: Ten Years After the East Bay Hills Fire; October 10-12, 2001; Oakland 
California. Technical Report 35.01.462. Richmond CA: University of California Forest Products Laboratory.

Bolte, J.P., Hulse, D.W., Gregory, S.V., Smith C., 2007. Modeling biocomplexity-actors, landscapes and alternative futures. Environmental Modeling and Software 22, 570-579.

Bowman, D.M., Balch, J.K., Artaxo, P., Bond, W.J., Carlson, J.M., Cochrane, M.A., D’Antonio, C.M., DeFries, R.S., Doyle, J.C., Harrison, S.P., Johnston, F.H., 2009. Fire in the Earth system. science, 324(5926), pp.481-484.

Bozek, M.A., Young, M.K., 1994. Fish mortality resulting from delayed effects of fire in the Greater Yellowstone Ecosystem. Western North American Naturalist 54, 91-95.

Bracken, L.J., Croke, J., 2007. The concept of hydrological connectivity and its contribution to understanding runoff-dominated geomorphic systems. Hydrologic Process 21, 1749-1763.

Bracken, L.J., Oughton, E.A., 2006. 'What do you mean?' The importance of language in developing interdisciplinary research. Transactions of the Institute of British Geographers 31, 371-382.

Bracken, L.J., Wainwright, J., Ali, G.A., Tetzlaff, D., Smith, M.W., Reaney, S.M., Roy, A.G., 2013. Concepts of hydrological connectivity: research approaches, pathways and future agendas. Earth-Science Review 119, 17-34.

Burke, M.P., Hogue, T.S., Kinoshita, A.M., Barco, J., Wessel, C., Stein, E., 2013. Pre- and postfire pollutant loads in an urban fringe watershed in Southern California. Environmental Monitoring and Assessment, http://dx.doi.org/10.1007/s10661-013-3318-9.

Cannon, S.H., Bigio, E.R., Mine, E., 2001. A process for fire-related debris flow initiation, Cerro Grande fire, New Mexico. Hydrological Processes 15, 3011-3023.

Cannon, S.H., DeGraff, J., 2009. The increasing wildfire and post-fire debris-flow threat in western USA, and implications for consequences of climate change, in: Sassa, K., Canuti, P. (Eds.), Landslides-Disaster Risk Reduction. Springer, Berlin/Heidelberg, pp. 177-190.

Chapin III, F.S., Hoel, M., Carpenter, S.R., Lubchenco, J., Walker, B., Callaghan, T.V., Folke, C., Levin, S.A., Mäler, K.-G., Nilsson, C., Barrett, S., Berkes, F., Crépin, A.-S., Danell, K., Rosswall, T., Starrett, D., Xepapadeas, A., Zimov, S.A., 2006. Building resilience and adaptation to manage Arctic change. AMBIO: A Journal of the Human Environment 35, 198-202.

Chin, A., 2006. Urban transformation of river landscapes in a global context. Geomorphology $79,460-487$.

Chin, A., English, M., Fu, R., Galvin, K., Gerlak, A., Harden, C., McDowell, P., McNamara, D., Peterson, W.J., Poff, L., Rosa, E., Solecki, W., Wohl, E., 2010. Landscapes in the "Anthropocene": exploring the human connections. Summary report of A NSF workshop held at 
the University of Oregon, Eugene, Oregon 4-6 March 2010. Available at http://clas.ucdenver.edu/ges/landscapes/ (accessed 15 May 2015).

Chin, A., Florsheim, J.L., Wohl, E., Collins, B.D., 2014a. Feedbacks in human-landscape systems. Environmental Management 53, 28-41.

Chin, A., Laurencio, L.R., Daniels, M.D., Wohl, E., Urban, M.A., Boyer, K.L., Gregory, K.J., 2014b. The significance of perceptions and feedbacks for effectively managing wood in rivers. River Research and Applications 30, 98-111.

Chin, A., An, L., Florsheim, J.L., Laurencio, L.R., Marston, R.A., Solverson, A.P., Simon, G.L., Stinson, E., Wohl, E, 2016. Investigating feedbacks in human-landscape systems: lessons following a wildfire in Colorado, USA. Geomorphology 252:40-50.

Chong, J., Renaud, J., Ailsworth, E., 2004. Flash floods wash away lives, dreams. Los Angeles Times (January 3, 2004, p. B.1).

Cohen, J., 2010. The wildland-urban interface fire problem: a consequence of the fire exclusion paradigm. Forest History Today 20-26.

Collins, B.D., Montgomery, D.R., Fetherston, K.L., Abbe, T.B., 2012. The floodplain largewood cycle hypothesis: a mechanism for the physical and biotic structuring of temperate forested alluvial valleys in the North Pacific coastal ecoregion. Geomorphology 139, 460-470.

Corenblit, D., Baas, A.C.W., Bornette, G., Darrozes, J., Delmotte, S., Francis, R.A., Gurnell, A.M., Julien, F., Naiman, R.J., Steiger, J., 2011. Feedbacks between geomorphology and biota controlling Earth surface processes and landforms: a review of foundation concepts and current understandings. Earth-Science Reviews 106, 307-331.

Davis, G.W. and Richardson, D.M. eds., 2012. Mediterranean-type ecosystems: the function of biodiversity (Vol. 109). Springer Science \& Business Media.

DeBano, L.F., 2000. The role of fire and soil heating on water repellency in wildland environments: a review. Journal of Hydrology 231-232, 195-206.

Dunham, J.B., Rosenberger, A.E., Luce, C.H., Rieman, B.E., 2007. Influences of wildfire and channel reorganization on spatial and temporal variation in stream temperature and the distribution of fish and amphibians. Ecosystems 10, 335-346.

Earl, S.R., Blinn, D.W., 2003. Effects of wildfire ash on water chemistry and biota in SouthWestern U.S.A. streams. Freshwater Biology 48, 1015-1030.

Ebel, B.A., John A.M, Deborah A.M, 2012. Hydrologic conditions controlling runoff generation immediately after wildfire. Water Resources Research 48.3. 
Emelko, M. and Sham, C.H., 2014. Wildfire impacts on water supplies and the potential for mitigation: Workshop Report.

Florsheim, J.L., Keller, E.A., Best, D.W., 1991. Fluvial sediment transport in response to moderate storm flows following chaparral wildfire, Ventura County, southern California.

Geological Society of America Bulletin 103, 504-511.

Folke, C., Hahn, T., Olsson, P., Norberg, J., 2005. Adaptive governance of social-ecological knowledge. Annual Review of Environment and Resources 30, 441-473.

Folke, C., Carpenter, S.R., Walker, B., Scheffer, M., Chapin, T., Rockstrom, J., 2010. Resilience thinking: integrating resilience, adaptability and transformability. Ecology and Society 15(4), 20. http://www.ecologyand society.org/vol15/iss4/art20/.

Gerlak, A.K., 2013. Policy interactions in human-landscape systems. Environmental Management 53, 67-75. http://dx.doi.org/10.1007/s00267-013-0068-y.

Gresswell, R.E., 1999. Fire and aquatic ecosystems in forested biomes of North America. Transactions of the American Fisheries Society 128, 193-221.

Gorte, R., 2013. The Rising Cost of Wildfire Protection. Headwaters Economics. http://headwaterseconomics.org/wildfire/fire-costs-background.

Haight R.G., Cleland D.T., Hammer R.B., Radeloff V.C., Rupp T.S., 2004. Assessing fire risk in the wildland-urban interface. Journal of Forestry 102, 41-48.

Hamin, E. M., and Gurran, N. "Urban form and climate change: Balancing adaptation and mitigation in the US and Australia." Habitat international 33.3 (2009): 238-245.

Harden, C.P., Chin, A., English, M.R., Fu, R., Galvin, K., Gerlak, A.K., McDowell, P.F., NcNamara, D.E., Peterson, J.M., Poff, N.L., Rosa, E.A., Solecki, W., Wohl, E., 2014. Understanding human-landscape interactions in the "Anthropocene." Environmental Management 53(1):4-13.

Hauer, F.R., Frissell, C.A., 2004. Postfire management on forested public lands of the western United States. Conservation Biology 18, 957-967.

IAWF, 2013. WUI Fact Sheet. International Association of Wildland Fire. http://www.iawfonline.org/pdf/WUI_Fact_Sheet_08012013.pdf

Isaak, D.J., Luce, C.H., Rieman, B.E., Nagel, D.E., Peterson, E.E., Horan, D.L., Parkes S., Chandler G.L., 2010. Effects of climate change and wildfire on stream temperatures and salmonid thermal habitat in a mountain river network. Ecological Applications 20, 1350-1371.

James, L.A., 2013. Legacy sediment: definitions and processes of episodically produced anthropogenic sediment. Anthropocene 2, 16-26. http://dx.doi.org/10.1016/j.ancene.2013.04.001. 
Jensen, S.E., 2006. Policy tools for wildland fire management: principles, incentives, and conflicts. Natural Resources Journal 46, 959-1003.

Johnson, B. R., Hulse, D.W., Neilsen-Pincus, M., Evers, C., Ager, A.A., Bolte, J.P., 2013. Climate change, oak savannas, urbanization and wildfire: dilemmas, tradeoffs and approaches for climate change adaptation planning. Program with Abstracts, $84^{\text {th }}$ Annual Meeting of the Northwest Scientific Association, 20-23 March 2013, Portland, OR.

Jones, R.D., Boltz, G., Carty, D.G., Kaeding, L.R., Mahony, D.L., Olliff, T., 1993. Fishery and aquatic management program in Yellowstone National Park. U.S. Fish and Wildlife Service, Technical Report for 1992. Yellowstone National Park, Wyoming.

Jones, R.D., Carty, D.G., Ewing, R., Gresswell, R.E., Koch, E.D., Mahony D.L., Mohrman, J.L., 1989. Fishery and aquatic management program in Yellowstone National Park. U.S. Fish and Wildlife Service, Technical Report for 1988, Yellowstone National Park, Wyoming.

Keane, R.E., Agee, J., Fule, P., Keeley, J., Key, C., Kitchen, S., Miller, R., Schulte, L., 2008. Ecological effects of large fires in the United States: benefit or catastrophe. International Journal of Wildland Fire 17, 696-712.

Kinoshita, A.M., Hogue, T.S., 2011. Spatial and temporal controls on post-fire hydrologic recovery in Southern California watersheds. Catena 87, 240-252.

Kinoshita, A.M., Hogue, T.S., 2015. Increased dry season water yield in burned watersheds in Southern California. Environmental Research Letters, 10(1), 014003.

Kristensen, L., Taylor, M., Odigie, K., Hibdon, S., Flegal, A., 2014. Lead isotopic compositions of ash sourced from australian bushfires. Environmental Pollution 190, 159-165. doi:

10.1016/j.envpol.2014.03.025

Kruger, F.J., Mitchell, D.T. and Jarvis, J.U. eds., 2012. Mediterranean-type ecosystems: the role of nutrients (Vol. 43). Springer Science \& Business Media.

Lane, P.N., Sheridan, G.J., Noske, P.J., Sherwin, C.B., Costenaro, J L., Nyman, P., Smith, H.G., 2012. Fire effects on forest hydrology: lessons from a multi-scale catchment experiment in SE Australia. IAHS Publ, 353, 137-143.

Lach, D., 2014. Challenges for linking quantitative and qualitative data and methods for investigating human-landscape systems. Environmental Management 53 (1): 88-93, http://dx.doi.org/10.1007/s00267-013-0115-8.

Liao, Kuei-Hsien. "A Theory on Urban Resilience to Floods--A Basis for Alternative Planning Practices." Ecology and Society 17.4 (2012): 48.

Loomis, J., 2004. Do nearby forest fires cause a reduction in residential property values?. Journal of forest economics, 10(3), 149-157. 
López-Marrero, Tania, and Petra Tschakert. "From theory to practice: building more resilient communities in flood-prone areas." Environment and Urbanization 23.1 (2011): 229-249.

Malison, R.L., Baxter, C.V., 2010. Effects of wildfire of varying severity on benthic stream insect assemblages and emergence. Journal of the North American Benthological Society 29, 1324-1338.

Marlon, J.R., Bartlein, P.J., Gavin, D.G., Long, C.J., Anderson, R.S., Briles, C.E., Brown, K. J., Colombarolig, D., Halletth, D.J., Poweri, M.J., Scharfj, E.A., Walsh, M.K., 2012. Long-term perspective on wildfires in the western USA. Proceedings of the National Academy of Sciences 109, E535-E543. doi: 10.1073/pnas.1112839109.

Mast, M.A., Clow, D.W., 2008. Effects of 2003 wildfires on stream chemistry in Glacier National Park, Montana. Hydrological Processes 22, 5013-5023. doi: 10.1002/hyp.7121

Meixner, T., \& Wohlgemuth, P., 2004. Wildfire impacts on water quality. Journal of Wildland Fire, 13(1), 27-35.

Merz, Bruno, et al. "Review article" Assessment of economic flood damage"." Natural Hazards and Earth System Sciences 10.8 (2010): 1697-1724.

Minshall, G.W., Robinson, C.T., Lawrence, D.E., 1997. Postfire response of lotic ecosystems in Yellowstone National Park U.S.A. Canadian Journal of Fisheries and Aquatic Sciences 54, 2509-2525.

Montz, B. E. "The generation of flood hazards and disasters by urban development of floodplains." Floods 1 (2000): 116-127.

Moody, J.A., Martin, D.A., 2001. Initial hydrologic and geomorphic response following a wildfire in the Colorado Front Range. Earth Surface Processes and Landforms 26, 1049-1070. Moody, J.A., Shakesby, R.A., Robichaud, P.R., Cannon, S.H., Martin, D.A., 2013. Current research issues related to post-wildfire runoff and erosion processes. Earth-Science Reviews, http://dx.doi.org/10.1016/j.earscirev.2013.03.004.

Moritz, M.A., E. Batllori, R.A. Bradstock, A.M. Gill, J. Handmer, P.F. Hessburg, J. Leonard, S. McCaffrey, D.C. Odion, T. Schoennagel, \& A.D. Syphard. 2014. Learning to coexist with wildfire. Nature 515:58-66.

National Research Council (NRC), 2011. New research opportunities in the earth sciences at the National Science Foundation (NROES). The National Academies Press, Washington DC.

Neville, H., Dunham, J., Rosenberger, A., Umek, J., Nelson, B., 2009. Influences of wildfire, habitat size, and connectivity on trout in headwater streams revealed by patterns of genetic diversity. Transactions of the American Fisheries Society 138, 1314-1327. 
Nyman, P., Sheridan, G.J., Smith, H.G. and Lane, P.N., 2011. Evidence of debris flow occurrence after wildfire in upland catchments of south-east Australia. Geomorphology, 125(3), pp.383-401.

Nyman, P., Smith, H.G., Sherwin, C.B., Langhans, C., Lane, P.N., Sheridan, G. J., 2015. Predicting sediment delivery from debris flows after wildfire. Geomorphology, 250, 173-186.

Odigie, K.O. and Flegal, A.R., 2011. Pyrogenic remobilization of historic industrial lead depositions. Environmental science \& technology, 45(15), pp.6290-6295.

Odigie, K.O. and Flegal, A.R., 2014. Trace metal inventories and lead isotopic composition chronicle a forest fire's remobilization of industrial contaminants deposited in the Angeles National Forest. PloS one, 9(9), p.e107835.

Odigie, K.O., Khanis, E., Hibdon, S.A., Jana, P., Araneda, A., Urrutia, R. and Flegal, A.R., 2016. Remobilization of trace elements by forest fire in Patagonia, Chile. Regional Environmental Change, 16(4), pp.1089-1096.

Paton, D., Buergelt P.T., McCaffrey S., Tedim F., Shroder J.F., 2015. Wildfire Hazards, Risks, and Disasters, Elsevier.

Peterson, J.M., Caldas, M.M., Bergtold, J.S., Sturm, B.S., Graves, R.W., Earnhart, D., Hanley, E.A., Brown, J.C., 2014. Economic linkages to changing landscapes. Environmental Management 53(1): 55-56, http://dx.doi.org/10.1007/s00267-013-0116-7.

Pettit, N.E., Naiman, R.J., 2007. Fire in the riparian zone: characteristics and ecological consequences. Ecosystems 10, 673-687.

Plate, E.J., 2002. Flood risk and flood management. Journal of Hydrology, 267(1), pp.2-11.

Poff, N.L., Allan, J.D., Bain, M.B., Karr, J.R., Prestegaard, K.L., Richter, B.D., Sparks, R.E., Stromberg, J.C., 1997. The natural flow regime. BioScience 47, 769-784.

Ranalli, A.J., 2004. A summary of the scientific literature on the effects of fire on the concentration of nutrients in surface waters, Open-File Report 2004-1296, U.S. Department of the Interior, USGS. Denver, CO.

Rieman, B.E., Lee, D., Chandler, G., Myers, D., 1997. Does wildfire threaten extinction for salmonids: responses of redband trout and bull trout following recent large fires on the Boise National Forest, in: Proceedings of the Symposium on Fire Effects on Threatened and Endangered Species and Their Habitats. International Association of Wildland Fire, Fairfield, Virginia, pp. 47-57.

Riggan, P.J., Lockwood, R.N., Jacks, P.J., Colver, C.G., Weirich, F., DeBano, L.F., Brass, J.A., 1994. Effects of fire severity on nitrate mobilization in watersheds subject to chronic atmospheric deposition. Environmental Science \& Technology 28, 369-375. 
Rinne, J.N., 1996. Short-term effects of wildfire on fishes and aquatic macroinvertebrates in the southwestern United States. North American Journal of Fisheries Management 16, 653-658.

Robichaud, P.R., 2000. Fire effects on infiltration rates after prescribed fire in Northern Rocky Mountain forests, USA, Journal of Hydrology 231-232, 220-229.

Robichaud, P.R, Wagenbrenner, J.W., Brown R.E., Spigel, K.M., 2009. Three years of hillslope sediment yields following the Valley Complex fires, western Montana. Research Paper RMRSRP-77. USDA Forest Service, Rocky Mountain Research Station, Fort Collins, Colorado.

Romme, W.H., Boyce, M.S., Gresswell, R., Merrill, E.H., Minshall, G.W., Whitlock, C., Turner, M.G., 2011. Twenty years after the 1988 Yellowstone Fires: lessons about disturbance and ecosystems. Ecosystems 14, 1196-1215.

Rulli, M.C., Rosso, R., 2007. Hydrologic response of upland catchments to wildfires. Advances in Water Resources 30, 2072-2086.

Santi, P.M., Hewitt, K., VanDine, D.F. and Cruz, E.B., 2011. Debris-flow impact, vulnerability, and response. Natural hazards, 56(1), pp.371-402.

Seastedt, T.R., Hobbs, R.J., Suding, K.N., 2008. Management of novel ecosystems: are novel approaches required? Frontiers in Ecology and the Environment 6, 547-553.

http://dx.doi.org/10.1890/070046.

Schumm, S.A., 1979. Geomorphic thresholds: the concept and its applications. Transactions of the Institute of British Geographers 4, 485-515.

Shakesby, R.A., Doerr, S.H., 2006. Wildfire as a hydrological and geomorphological agent. Earth-Science Review 74, 269-307.

Sheridan, G.J., Lane, P.N., Noske, P.J., 2007. Quantification of hillslope runoff and erosin processes before and after wildfire in a wet Eucalyptus forest. Journal of Hydrology 343, 12-28.

Sibold J.S., Veblen, T.V. and Gonzalez, ME, 2006. Spatial and temporal variation in historic fire regimes in subalpine forests across the Colorado Front Range in Rocky Mountain National Park, Colorado, USA. Journal of Biogeography 32, 631-647.

Silins, U., Stone, M., Emelko, M.B., Bladon, K.D., 2009. Sediment production following severe wildire and post-fire salvage logging in the Rocky Mountain headwaters of the Oldman river basin, Alberta. Catena 79, 189-197.

Simon G., 2012. Development, risk momentum and the ecology of vulnerability: a historicalrelational analysis of the 1991 Oakland Hills firestorm, in: Dooling, S., Simon, G. (Eds.), Cities, Nature, Development: The Politics and Production of Urban Vulnerabilities. Ashgate Publishing, Aldershot, UK, pp. 23-48. 
Smith, H.G., Sheridan, G.J., Lane, P.N., Nyman, P., Haydon, S., 2011. Wildfire effects on water quality in forest catchments: a review with implications for water supply. Journal of Hydrology 396, 170-192.

Spracklen, D.V., Mickley, L.J., Logan, J.A., Hudman, R.C., Yevich, R., Flannigan, M.D., Westerling, A.L., 2009. Impacts of climate change from 2000 to 2050 on wildfire activity and carbonaceous aerosol concentrations in the western United States. Journal of Geophysical Research: Atmospheres (1984-2012), 114(D20).

Spencer, C.N., Hauer, F.R., 1991. Phosphorus and nitrogen dynamics in streams during a wildfire. Journal of the North American Benthological Society 10, 24-30.

Stein, E.D., Brown, J.S., Hogue, T.S., Burke, M.P., Kinoshita, A., 2012. Stormwater contaminant loading following southern California wildfires. Environmental Toxicology and Chemistry 31, 2625-2638.

Suriya, S., and B. V. Mudgal. "Impact of urbanization on flooding: the Thirusoolam sub watershed-a case study." Journal of Hydrology 412 (2012): 210-219.

Tapsell, Sue M., et al. "Vulnerability to flooding: health and social dimensions." Philosophical Transactions of the Royal Society of London A: Mathematical, Physical and Engineering Sciences 360.1796 (2002): 1511-1525.

Townsend, S.A., Douglas, M.M., 2004. The effect of wildfire on stream water quality and catchment water yield in a tropical savanna excluded from fire for 10 years (Kakadu National park, North Australia). Water Research 38, 3051-3058.

Tretter, Eliot M., and Melissa Adams. "The Privilege of Staying Dry: The Impact of Flooding and Racism on the Emergence of the "Mexican" Ghetto in Austin's Low-East side, 1880-1935." Cities, Nature and Development: The Politics and Production of Urban Vulnerabilities S. Dooling and G. Simon, eds (2012): 187-206.

Troendle, C.A., Bevenger, G.S., 1996. Effect of fire on streamflow and sediment transport Shoshone National Forest, Wyoming, in: Greenlee, J. (Ed.), The ecological implications of fire in Greater Yellowstone: Proceedings of the second biennial conference on the Greater Yellowstone Ecosystem. International Association of Wildland Fire, Fairfield, Washington, pp. 43-52.

Veblen, T.T., Kitzberger, T., Donnegan, J., 2000. Climatic and human influences on fire regimes in ponderosa pine forests in the Colorado Front Range. Ecological Applications 10, 1178-1195.

Verkaik, I., Rieradevall, M., Cooper, S.D., Melack, J.M., Dudley, T.L., Prat, N., 2013. Fire as a disturbance in mediterranean climate streams. Hydrobiologia, http://dx.doi.org/10.1007/s10750013-1463-3. 
Vieira, N.K., Clements, W.H., Guevara, L.S., Jacobs, B.F., 2004. Resistance and resilience of stream insect communities to repeated hydrologic disturbances after a wildfire. Freshwater Biology 49, 1243-1259.

Warziniack, T. and Thompson, M., 2013. Wildfire risk and optimal investments in watershed protection. In Western Economics Forum (Vol. 12, No. 2, pp. 19-28). Western Agricultural Economics Association.

Wagner, D.L., De Graff, J.V. and Lancaster, J.T., 2013. Debris flows in the southern and eastern Sierra Nevada region, California. Field Guides, 32, pp.99-128.

Wineke, A., 2012. Waldo Canyon Fire Most Expensive in State History. The Gazette. Available online at.http://gazette.com/waldo-canyon-fire-most-expensive-in-state-history/article/141783. Published July 17, 2012.

Wohl, E., 2013. Wilderness is dead: whither critical zone studies and geomorphology of the Anthropocene? Anthropocene, http://dx.doi.org/10.1016/j.ancene.2013.03.001.

Wohl, E., Gerlak, A.K., Poff, N.L., Chin, A., 2014. Common core themes in geomorphic, ecological and social systems. Environmental Management 53,14-27.

Wohl, E., Merritt, D., 2007. What is a natural river? Geography Compass 1, 871-900.

Young, D., Rust, B., 2012. Waldo Canyon Fire - Burned Area Emergency Response Soil Resource Assessment. USDA Forest Service, Region 5, Redding CA.

Zvoleff, A., An, L., 2014. Analyzing human-landscape interactions: tools that integrate. Environmental Management 53(1): 94-111, http://dx.doi.org/10.1007/s00267-012-0009-1. 